\title{
Types, Characteristics, Organization and Management of Primary and Secondary Schools in the Democratic Republic of the Congo
}

\author{
MFIYA LUNGA FANNY \\ College of Education, Nanjing Normal University, Gulou district, 122 Ninghai road Nanjing, China \\ Email: funnymfiya@yahoo.fr
}

\begin{abstract}
The education system in the DRC will play an important role in rebuilding the country's political institutions, stimulating growth and correcting inequalities. The management of an education policy consistent with general political and economic objectives is essential for the formulation of a comprehensive policy for the development of the country.The Congolese education system continues to develop slowly at all levels, despite the failure of public finances over the past two decades, economic chaos, political instability and war. Disorder and conflict in the second half of the nineties seem to have hindered primary education more than other levels of education. Enrolment growth has been the fastest in higher education. The growth of private institutions has far outpaced that of public institutions at all levels. However, this growth is relative to very low initial enrolment, so the public sector continues to be predominant at all levels, especially thanks to the free basic education advocated by the current Head of State.This study presents the types and characteristics of primary and secondary schools in the DRC in the current socio-economic context with a view to its improvement in the coming days and analyses recent trends and the current state of management of different levels of education in the DRC; highlighting both national characteristics and differences between provinces and social groups. It also presents a simulation of the financial implications of different education policy options, which may be useful for undertaking more precise planning of the sector.
\end{abstract}

Keywords: primary education, secondary education, basic education Management, organization

DOI: $10.7176 / \mathrm{JEP} / 13-6-07$

Publication date: February $28^{\text {th }} 2022$

\section{Introduction}

The education system of the Democratic Republic of Congo (DRC) continues to develop at all levels, although slowly and with ups and downs. However, this trend, surprising in a context of more than two decades of economic decline, nearly a decade of conflict and free basic education, so far shows no decisive progress towards universal primary schooling.

In fifteen years, the proportion of out-of-school children, although of primary school age, has increased; many of those who attend primary school do so irregularly and among those who manage to reach the last year of primary school, very few are able to understand what they are reading or write simple sentences. Quality is low at all levels of the education system, and the content and standards of secondary and higher education have not been reformed for more than twenty years.

Free education has supported the modest expansion of the education system and prevented its decline. The continued growth of the education system and its funding by the Congolese government under extremely adverse circumstances reflect a long tradition of commitment to education and a strong demand for education. They also reflect families' expectation that investing in their children's education is the best guarantee of benefiting from future economic recovery and growth, although current wages in the labor market do not provide a satisfactory monetary return on education.

The structure of the Educational System The duration of compulsory education is 6 years for children between 6 and 11 years of age. Although 3-year preschool is planned, it is offered in practice only in a few urban areas and for a year or two, with a class for 5-year-olds and a single class for 3-4 years old. Primary schooling of 6 years is divided into three degrees of two years each. The primary school leaving certificate is granted on the basis of an assessment of the student's class results and grades on a national test (TENAFEP).

Secondary education consists of a long cycle and a short cycle. Three general, pedagogical and technical sections are proposed in the long cycle. This cycle consists of a first stage of two years the common core common to the three sections, and a second stage of four years which introduces the differentiation between the three sections. Within each section, various options are offered, up to thirty options in the technical section. Although there is some specialization of the institutions, as in some autonomous technical schools, many secondary schools, especially in Kinshasa, offer the three sections and different options in each of them. The short cycle concerns vocational education, which consists of 4-year training, which begins immediately after primary education, or 3year training after the common core of secondary education. There are thirty-three options in vocational education. 
In addition, there are arts and crafts schools that offer craft training in three or four years.

Entry into higher education is conditional on obtaining a State Diploma which certifies the end of the long cycle of secondary education; this diploma takes into account the results of a national examination and continuous monitoring; secondary vocational education does not provide access to higher education. Entrance exams are organized by a few rare establishments. Higher education consists of a three-year first cycle and a two-year second cycle. These courses of study are offered at universities and non-university institutes. These include institutes of technology that train technicians (the Higher Technical Institutes, IST), pedagogical institutions that train secondary school teachers, (the Higher Pedagogical Institutes, ISP) and institutes that combine these two functions (the Higher Pedagogical and Technical Institutes, ISPT).

Apart from the introduction and conclusion, this study has 3 points namely: (1) definition of concepts and (2) Types and characteristics of primary and secondary schools in the DRC and (3) the organization and management of basic education in the DRC.

\section{DEFINITION OF CONCEPT}

\subsection{Primary education}

Primary education, or primary school, is in several countries the first stage of education. It allows in particular the learning of reading, writing and the basics of mathematics. Children begin primary education around the age of 6 and complete it around the age of 11 (UNESCO, 2021).

\subsection{Secondary education}

Secondary education covers the school levels between the end of primary school and the beginning of higher education. The systems adopted by the different countries are very varied (UNESCO, 2021).

\subsection{Basic education}

It is the set of different programs of educational activities aimed at meeting basic educational needs, as defined in the World Declaration on Education for All. According to the ISCED classification, basic education comprises primary education (first stage of basic education) and lower secondary education (second stage). It also covers a very diverse set of non-formal and informal educational activities, both public and private, aimed at meeting the specific basic educational needs of groups of people of all ages (MURHEGA M., 2015, p. 52).

\subsection{Management}

The concept of management comes from the verb to manage, from the Latin "gevere" which wants, in a broad and etymological way, to say: to administer. Example: managing educational activities. The term management can be defined as the rational and intelligent use of the resources made available to the company. The word manage means to rationally use the human, financial and material resources made available to the school to ensure its profitability, that is to say the profit obtained in relation to the means committed (www.wikipedia.org).

\subsection{Organization}

According to Larousse dictionaries, the word organization refers to the action and effect of organizing, developing or structuring. So, you might think that an organization is a group of people who come together for a certain reason. and with a common goal, who communicate with each other and carry out both individual and common activities.

These organizations, in turn, could differ according to their more spontaneous or formal nature. We are talking about those that are not formed explicitly and formally in the face of those that are constituted on the basis of welldefined objectives.

An operational structure, with concrete activities and established methods, is defined around these objectives. 2.5.1 School organization

We are talking about an educational institution, which is a formal type of organization. It has a well-defined structure in which specific tasks and activities are carried out and where there are distinct and differentiated roles.

Precisely, the study and analysis of these educational institutions, their elements and the methods used in them, constitute the conceptual and knowledge base from which the theory of school organization develops.

2.5.2 Features of school organization theory

There are many definitions proposed by different authors on what is the theory of school organization. However, all agree that it is a scientific discipline drawn from other organizational theories from the business world applied to the study of educational institutions.

A theory of school organization is based on knowledge of the educational institution as an object of study. It analyses how the different elements forming the establishment should interact.

In this sense, the theory of school organization is not limited to the discovery of the organizational phenomenon. It also has a normative scope on how organizational action should promote its operation.

The different elements that make up the school center are as well human and material resources, as well as 
administrative and legislative organizations that must function in such a way as to guarantee the education of pupils (https://etreparents.com/la-theorie-de-lorganisation-school-and-its-characteristics).

\section{TYPES AND CHARACYERISTICS OF PRIMARY AND SECONDARY SCHOOLS}

\subsection{Evolution of the Congolese education system}

The Congolese education system has undergone changes during different eras that have marked the history of the Democratic Republic of Congo.

\subsubsection{The Belgian colonial education system}

It is very well known that Belgium had Burundi, Rwanda and the current DRC as colonies. In the Belgian education system, there have been four stages of development of education in all the colonies, even corresponding to the status of these territories (MURHEGA, M, 2016, p.27). However, we note four stages in the evolution of the education system in the Democratic Republic of Congo.

\subsubsection{First the period of the Congo Free State of 1885-1909}

This is the period when the Congo was the private property of the Belgian King Leopold II. At that time, there was an attempt to educate the children but that did not make oil stain; the idea turned around the death of its initiator. This is what led to the idea of creating schools of the colonies from the $1890 \mathrm{~s}$. He had colonies where free children were recovered, children abandoned by parents to be placed under state guardianship until the age of 25 to undergo military training. Religion, reading, local languages, French, writing and arithmetic were taught. Later, there were schools created according to certain needs. In the missionary network, a religious program was given to train catechists The purpose was to prepare the proselytes and subsequently for economic purposes there was the creation of vocational schools.

Towards the end of the 19th century, there was an attempt at interference as the state began to take an interest in these missionary schools. In 1906, there was the Concordat, that is, the first document that stipulated the agreement between the State and the Church. In this document identified an agricultural and vocational orientation given to the official school and an inspection was provided. It was necessary to teach in French and the State granted the missionaries land and other facilities for the installation and creation of schools.

3.1.3 Following the period of the colony of the Belgian Congo (1909-1914)

At that time two educational networks were created. These are subsidized schools and non-subsidized schools. This last network consisted of schools that trained religious catechists, priests. This situation prevailed until 1914. At that time, there was the difference in the level of education between the cities and the countryside. In 1920, in the countryside, the program included writing, calculation, arithmetic, manual work, and writing as subjects. In the cities, in addition to these disciplines, history, geography, hygiene, natural sciences and morals were planned. Voluntary discrimination was also evident between national and Catholic missions, between the teaching given to Belgians and the colonized. There have been schools for indigenous people and schools adapted to African needs. 3.1.4 Also, the period between the two wars

Changes were noticed between 1922 as a result of the work of the FRANK commission, which undertook to study the situation of Congo-Belgian education and proposed to make suggestions for reform. The document that comes out on this date is the report of the FRANK commission which reorganizes education in order to allow the public authorities to better control the education system. Here are some of the principles and recommendations of the commission's work:

- adapt the program and methods to the indigenous environment

- Teaching must take place in indigenous language

- Organize mass education.

- Create many normal schools and multiply many small schools for boys and girls.

- Solicit the collaboration of the Belgian national missions (religious missions) to spread with the help of the Gospel the love of the Belgians, the Belgian influence even in the most remote corners of Africa.

In 1929, another document focused on "organization of free education in Congo and Rwanda Urundi". In the new organizations, three types of schools were planned:

- First grade of Primary schools: located either in rural or urban areas. Literary education was reduced, schooling was two years. The teachers were made up of local monitors.

- Secondary primary schools: type of schools located in Europeanized centers. Literary education was very developed there. Schooling was three years.

- Special schools: where teachers (teacher training colleges), clerks (vocational schools), etc. were trained.

3.1.5 Finally, the period after the Second World War

During this period, there were no significant changes until the end of the 50s. It should rather be pointed out that in 1948 a reform took place which was implemented ten years later. It is a reform developed to Europeanize the system to introduce Belgian curricula in the colonies (tendency to assimilation), to improve teaching and raise the level of teachers. Before 1948, education was adapted to the level of the colonies.

At independence, unlike other countries, where there was a trained elite, there were no academics or qualified 
executives to take over from the Belgians. In fact, the universities (such as Lovanium and that of Elisabethville) opened in 1954 and 1956 were not open to the natives except for a few rare cases of the evolved

\subsubsection{The postcolonial and contemporary period}

This second period is characterized by the establishment of national systems and school reforms. During this period, UNESCO has played a great influence on the development of education policy not only in the DRC but also in Africa in general, and throughout the world.

\subsubsection{UNESCO's influence in improving education systems}

According to the report of the Lagos Conference (Report of the Lagos Conference, 1976, pp 13-64), it appears that UNESCO has played a great partnership role in the education system of African States in general and in particular the DRC. In May 1961, thirty-nine independent African states met in Addis Ababa at the first conference of African states on the development of education in Africa. The conference was jointly organized by UNESCO and ECA (United Nations Economic Commission in Africa). The first objective of the conference was to provide a forum for African states to decide on their educational needs with a view to promoting social and economic development. The second objective was to establish an attempt at a short- and long-term plan for the development of education, a plan that included priorities in relation to economic and social potential.

The conference had focused on school reforms, curriculum content, the importance of meeting the needs of skilled labor and cadres to replace whites; hence the need to increase secondary schools and the development of post-secondary structures.

The concern to increase secondary school enrolment was a primary objective before the structures of primary education in the event that financial possibilities did not allow for receiving both systems at the same time. For the primary level, there was talk of achieving widespread literacy and 100\% school enrolment in 1980 .

Around the 1980s, this period was characterized by a series of reforms. In the mid-70s, African states sought to readjust or replace their education systems. The aim of these reforms was to reduce the unemployment of young people who leave school for the rural exodus, to enable them to contribute to national development.

During this period, our country had failed to build school infrastructure or, one would say, public schools capable of receiving the entire school-age population. It was in these circumstances that an agreement was signed between the Congolese State, Zairean's at the time and the religious denominations in 1977, hence the name "Schools Under Agreement". Religious denominations had received legal authorization to establish and manage schools, and the state in turn should provide them with the fund for their operation and the care of teachers. It was in the same circumstances that private schools were also created.

Seeking to secure control of the education system as a political means as part of the nation-building project, President Mobutu's regime proceeded with the nationalization of schools in 1974, a measure known as the nationalization of schools.

Three years later, in 1977, the schools were returned to their founders (Churches). To this end, an agreement has been signed between the State and the latter. In this convention, it is clearly stipulated that the former is the organizing power of the schools, the latter simply enjoying the status of managers.

Under this agreement, all Catholic, Protestant and Kimbanguism schools have now become under agreement. From 1977 on, therefore, the DRC's education system included two main categories of schools: public schools and private schools.

\subsubsection{Objectives and principles of the Congolese education system}

The objectives and principles of the Congolese education system do not deviate from those of other states in subSaharan Africa except in their implementation.

a. Objectives

The Congolese education system has the objectives of promoting the physical, mental and moral development of the person, acquiring a sense of creativity compatible with a practical sense, helping children to acquire the basic abilities that allow them to speak, read, calculate and develop in them the faculties of reasoning of the ability to adapt to the evolution of the world and promote civic and patriotic feelings.

b. Principles

By its public nature, education must be secular, compulsory and partially free, school must be democratic, the system must be adapted to local realities and needs, the system must promote research that can contribute to national development and finally, the system must encourage community, collective work and ensure a prosperous future for citizens.

With regard to the administration and management of the education system, it is governed by the Ministry of Primary, Secondary and Vocational Education; currently referred to as the Ministry of Secondary Primary Education and Initiation to the New Citizenship and the Ministry of Higher and University Education.

\subsection{Education legislation in the DRC}

In the DRC (), the management of establishments is governed by laws and specific regulations. These are made possible with a view to ensuring quality education for pupils and good administration of central services such as 
those decentralized in the education sub-sector, working conditions in the secondary and vocational primary education sub-sector. These legal provisions are aimed at improving working conditions in the sub-sector of secondary and vocational primary education. The texts governing the legislation of the Congolese education system are part of the framework law ${ }^{\circ}{ }^{14 / 004}$ of February 11, 2014.

This framework law on education on the management and regulation of the EPSP divides the competences between the State and the decentralized entities with regard to the organization of national education. Teaching staff are divided into two categories:

- administrative staff: includes all teachers of the Collaboration and Execution Command.

- teaching staff: includes the teacher, the teacher, the work instructor, workshop leaders and the teacher.

As regards the organization of the Congolese education system, three key ministries share responsibility for the education sector. These are the Ministry of Primary, Secondary and Vocational Education (EPSP), the Ministry of Higher Education and Scientific Research (ESURS) and the Ministry of Social Affairs (MAS). Each of these ministries is headed at the central level by a Minister appointed by presidential order. At the provincial level, by a Ministry appointed by the Governor and accountable to the provincial parliament.

All the administrative and pedagogical services of each Ministry are placed under the direction of a Secretary General (SG) who implements the Policy of the Government and ensures the sustainability of the administrative action. The Ministry of Primary, Secondary and Vocational Education (EPSP) comprises three levels: nursery, primary and secondary.

\subsection{Defined criteria for the creation of private school}

Given the proliferation of private schools in the area under study, we sought during our investigation to reassure ourselves whether there really are well-defined criteria for the creation of a private school. This is how we contacted various stakeholders in this field of education, including the promoters and presidents of private school associations. During our interview with these different personalities, we managed to identify certain criteria defined by law for the creation of private schools. These criteria concern the personality of the initiator (promoter) as well as the procedure to be followed to create the school. These criteria are developed in the following points.

a. The personality of the promoter

The promoter must be a legal or natural person with in its attributions civic and legal, financial and material, environmental guarantees and those of moral, pedagogical, andragogic, academic, and administrative supervision. As for the natural person, he must be of Congolese or foreign nationality presenting these aforementioned guarantees welcomes the right to create a private institution of nursery education; primary, secondary and vocational. These criteria remain the same for the legal person.

Legal and civic guarantees mean a number of the criteria for the legal person and the natural person. For the legal person, it must have a legal personality, have not been convicted of economic crimes in the last ten years, comply with the laws of the Republic, have qualified management staff with at least five years' experience in the field of education. For the natural person, he must be at least thirty years old, present a certificate of good conduct, life and morals, comply with the laws of the Republic, have qualified management staff with at least five years of experience in the field of education, have not been convicted of economic crimes or any other intentional offence. For this concerning financial and material guarantees, the promoter must meet the following criteria:

- The existence of viable infrastructure as well as appropriate clean equipment

- The six-month term deposit in a banking or financial institution in the Democratic Republic of Congo of the sum necessary for the operation of the educational institution, as well as the pay of the teaching and administrative staff for at least one year.

- The holding of the title deed of the site and the buildings intended to accommodate the educational institution or, where applicable, a duly legalized building lease contract for a minimum period of six years.

- The certificate indicating the area of the site conforming to the standard of at least $5 \mathrm{~m}$ squares per student.

With regard to environmental guarantees, it is necessary to understand the possession of the certificate of the study of the environmental and social impact of the place of establishment of the establishment.

As for the guarantees of moral, pedagogical, andragogic, academic and administrative supervision, they relate to the following criteria:

- Has the opportunity to offer students and staff an educational environment capable of promoting the formation of the family and democratic spirit, national science, pride in their cultural identity and human dignity.

- In the file of the teaching staff, andragogic and administrative permanent, qualified and competent.

- In accordance with the structures and curriculum of national education.

Compliance with the minimum and maximum number of students, and administrative staff meeting the pedagogical and andragogic standards set by regulation.

b. Procedures for setting up a private school

After analyzing the results of our research, we have identified two main procedures for the accreditation of a nursery, primary, secondary and vocational educational institution. These procedures are detailed in the following 
points:

a written request addressed to the Ministry of the provincial and/or national government having in its attribution's nursery, primary, secondary and vocational education. The application must include the name and structures requested, the objectives and aims pursued by the institution, the designation of the place where the school is located, the brief description of the premises, the note on the person of the promoter, the note on the person in charge of the management of the establishment, the list of staff members, the curricula, the estimate of the number of students who will attend the school in all cycles, the amounts of the parents' participation, a copy of the statutes of the establishment, the list of teaching materials necessary for the execution of the program, the bank account, the and the note demonstrating that the institution meets the geographical, pedagogical and economic needs.

- an investigation whose conditions are defined by the laws of the operation of an educational institution, sanctioned by a decree of the Ministry of the Provincial and / or Central Government having in its attributions, nursery, primary, secondary and vocational education.

These private establishments are subject to administrative, financial and health pedagogical control according to the modalities determined by regulation. Approval shall be withdrawn when the conditions of opening and operation no longer meet the standards defined by the State or if it is established that it has been obtained irregularly. The withdrawal of the approval entails the closure of the establishment.

As can be observed, these previously defined criteria are reliable and taxpayers to quality education. Unfortunately, most private schools in the municipality of Ibanda do not meet these criteria. Nor, despite this deviation from the standards, these schools do not suffer the withdrawal of accreditation.

\subsection{Financial organization of the Congolese education system}

The Congolese education system includes different sources of funding for its proper functioning. However, the financing of the Congolese education system emanates from the high patronage of the State as governed by the texts. Nevertheless, this statement seems to be a paradox in the eyes of Congolese citizens. A very small budget is allocated to the education sector and as a result the financial organization becomes very weak. Over the past ten years, the budget allocated to the education sector has not been more than 5\% (MURHEGA M., 2015, p.52).

This shows that the Congolese State has not been given the task of taking full charge of the financial organization of the education system. There is no publication showing the breakdown by item of the education budget. Detailed budget documents and reports on expenditures are not available to anyone outside the ministry, making it impossible to know the sources and purposes of funding or to assess the extent to which expenditures are actually aligning with priorities in the education planning process.

Indeed, the private sector plays a major role in financing the Congolese education system. As far as teachers' pay is concerned, those in private schools do not receive any share from the State. Nor is the State involved in the purchase of school supplies, or the operation or even the construction of private schools. It would therefore be noted that in a way the State encourages the private sectors of education in the sense that they minimize public spending.

To be more precise, the funding of the Congolese education system comes on the one hand from the Congolese State and on the other hand from the initiatives of the parents of students. The State intervenes only in the financing of public schools. On the other hand, parents are involved in the financing of public and private schools. They pay the premium, the construction cost, and other operating costs to name a few.

\subsection{Structures of the Congolese education system}

In the Democratic Republic of Congo, education is organized according to prescribed cycles. We can then mention the nursery, primary, secondary cycle, etc. In addition to the different cycles, it should be noted that the schools belong to different management networks, including religious denominations (Catholic, Protestant, Kimbanguism, Muslim), official schools and private schools.

\subsubsection{Kindergarten}

In the DRC, kindergartens are part of the private sector. These schools are not often subject to control by the EPSP, so there is a curriculum overflow, schools learn subjects planned for primary school, but the most frequent case is 3 levels. The nursery cycle is subdivided into different levels in relation to the age of the learners. This is to adapt the teaching to each child. This environment aims not only at intellectual education but also at the supervision of children. This is why some schools even organize the nursery level to supervise young children. In this cycle, different games are planned for the psychomotor development of children. The nursery cycle is optional. Children can enter primary school without having gone through kindergarten.

3.6.2 Primary school

This cycle brings together schools belonging to different networks: official, Catholic, Protestant, Kimbanguism and Islamic. The private sector also includes a large number of primary schools. The primary cycle receives not only children who come fresh from the nursery cycle but also those who come fresh from home. The end of the 
primary cycle is attested by a certificate of primary study to allow the recipient to undertake his studies in the secondary cycle. It is without this knowledge the national test is planned for students of classes of 6th year primary. In the DRC, this test has been given several names over the years, but the objective is still the same: to evaluate students in order to face the secondary cycle. Currently, this test is called TENAFEP, which means "National Test for the End of Primary Studies".

3.6.3 Secondary school

Ordinances No. 63 of 17 July and No. 110 of 24 July 1962 had been the subject of the organization of an orientation cycle which will lead to the upper cycles of secondary schools divided into short and long cycles. The purpose of the short cycle is vocational training. It is composed of different sections and extends over two or four years of study. On the other hand, the cycle is not only to obtain a state diploma, but also to undertake higher and university studies. The State Examination created in 1966-1967 also introduces general culture tests established for them. An order test for all candidates. Secondary schools organize different sections according to the orders at their disposal.

\subsection{Comparison between the private and public education sectors}

Establishing the difference and the resemblance between the schools of two networks: private and public is still a question that has not yet found the real answer. In most societies, one wonders what the real difference is. In this angle, a survey was carried out within some schools in the West (Great Britain and France). The survey result reveals that the difference is not significant from a formative point of view. However, there are differences at some administrative level. The result uses five key characteristics below (Ministry of EPSP, 2014).

- The same training. Candidates for private education competitions undergo the same tests as candidates in the corresponding public education competitions. Their level of training is therefore the same.

- A different status. Teachers in private schools under contract, and although paid by the State, do not have the status of civil servants. They are contract agents under public law. A private teacher receives the same gross salary as a public teacher, but his net salary is about $5 \%$ lower, due to higher employee contributions than in the public sector. In the second public level, the teaching staff is mainly composed of certified $(64.6 \%)$, vocational high school teachers $(15.3 \%)$ and aggregates $(13 \%)$. In the private sector, certified students are also in the majority $(61.6 \%)$, ahead of vocational high school teachers $(11.5 \%)$. On the other hand, only $4 \%$ of teachers are aggregates.

- The same programs. Private schools associated with the State participate in the public service mission of the National Education. Education is therefore provided in accordance with the curricula in force in public education, but the school life, pedagogical methods and general organization of the school are specific to it.

- Almost identical class sizes. Contrary to popular belief, private schools do not have fewer students per class. In 2010, according to an OECD study, the average class size in private and public primary schools in France was almost identical (just under 25 students), or even a little higher in the private sector. At the beginning of the 2014 school year, according to the Ministry of Education, the average number of students per class in the first degree was 23.7 for the public and 24.4 for the private. In private colleges, classes have an average of two more students than public colleges. On the other hand, the number of pupils is slightly lower in the classes of private lycées than in those of public lycées.

- What are the results? It is difficult to compare the success of private and public students throughout schooling. What can be said is that at the baccalaureate, on average, the success rate is higher in the private sector. Of the 31 general education high schools that obtained a success rate of at least $98 \%$ in the 2015 session in Brittany, 24 are private. In Morbihan, the ten public general education high schools have an overall success rate of $92 \%$, while the eleven private ones are at $97 \%$. In the Cotes-d'armor, the ten public high schools have an overall success rate of $91 \%$, compared to $95 \%$ for the eleven in the private sector. In Finistere, the twenty public high schools obtained an overall success rate of $93.6 \%$, compared to 96.78 for the nineteen in the private network.

- The private sector is no more selective. Could the best results in the private baccalaureate be explained by the fact that its schools would not keep their bad students? Clearly, would they be selective? If some private high schools tend, indeed, to select their students to ensure good success rates, we cannot say that this is the case in the Academy of Rennes. Proof of this is the added value of the access rate, which in a way measures the willingness of schools to support all their students up to the baccalaureate. According to other sources, (MOKONZI G., 2009, p. 148) between the public and the private under contract it is the same programs that must be followed and the training of teachers is the same: they go through the IUFM all except the substitutes whether public or private.

Then there is a question of price, but the private also applies the family quotient so we find all the social levels in private schools except in the very famous ones which are so much in demand that they sort by the price.

After all, it depends on whether you want your child to follow a religious education (compulsory in private school at least in primary school) or not and if it satisfies your convictions, and then it also depends on your place 
of life: very often we also school in private to avoid sensitive areas when we live in a mixed neighborhood.

Indeed, each community / individual appreciates this or that other network differently from the other, this being because the schools belonging to the same network do not have the same mode of operation. In other terms, some private schools are well known compared to public schools and vice versa. According to the statements made public (http://www.telegramme.fr/decriptage/effectifs), some parents prefer to send their children to private schools than to public schools to minimize the failure rate that leads to the waste of money. Other statements are illustrated in the following paragraphs.

In the private sector, teachers take into account the personality of each child, whoever he is, wherever he comes from, pedagogy is exclusively focused on the success of each child. In the public, teachers, whatever they say or want to prove, are always complaining about their working conditions, either they do not have enough equipment, or classes are overcrowded, or parents resign, or children are difficult, in short, the success of their students is important for only $20 \%$ of teachers in the public who, indeed take their profession to heart. They recognize that children are the main sources of finance, unlike in public schools where only the state is the main boss.

The big difference: the blatant affection of teachers for our children in the private sector, while in the public sector, our children are simply their working tools. Thus, all private and public schools operate according to the same curriculum established by the responsible Ministry, despite the irregularities that characterize some private schools with regard to the standards established for the operation of a school.

It is therefore not necessarily a matter of saying that private schools are less important than public schools or vice versa. In the DRC, these two education sectors do not differ from a program point of view.

\section{ORGANIZATION AND MANAGEMENT OF PRIMARY AND SECONDARY EDUCATION}

\subsection{At the national level}

Four actors are involved in the administration of primary and secondary education: the central government and the Ministry of Education; provincial administration; representatives of the four main religious congregations; and parents. Between 1997 and 2003, at the central level, there was a single Ministry of Education, comprising three sub-sectors, each with an administration headed by a Secretary General: Primary and Secondary Education (EPS), Higher and University Education (ESU) and Scientific and Technological Research. In 2003, the Ministry was split into a Ministry for Primary, Secondary and Vocational Education (Ministry of Primary, Secondary and Vocational Education-MEPSP), and a Ministry for Higher Education and Research (Ministry of Higher and University Education-MESU) (MINEPSP, 2014).

\subsection{At the provincial level}

The governor is in charge of the general administrative control of all sectors, including education. At the provincial level, the Secretary General is represented by the Head of Provincial Division (Proved), who is under the administrative control of the Governor, but who, for technical matters, reports to the MEPSP. Below the provincial level, the Proved is represented by the heads of sub-divisions (sub-Proved). The sub-Proved has three departments concerning personnel and finance, pedagogy, and planning. In practice, these services lack staff and resources and are not able to play a significant role in the administration of education.

The other two entities concerned with the administration of education, the churches and the parents' associations, are of a non-governmental nature. The division of responsibilities between the state and the churches has remained unclear since the nationalization of private schools in 1974 and their handover in 1977. The result has been an increase in administrative structures, the financing of which represents an additional burden for parents.

In 1977, the state signed an agreement with the four main churches (Roman Catholic, Protestant16, Kimbanguism and Islamic), according to which the churches must provide education in accordance with government directives. These guidelines concern school curricula, class size standards, teachers' qualifications and salaries, and the evaluation system. An important provision of the convention is that the churches manage the schools, although these belong to the state that is the organizing power.

However, in 1986, the framework law gave the Ministry of Education the general power to coordinate all educational authorities and no reference was made to church networks. A National Council of Education, in which both the government and the networks were represented, was created to set up coordination at the national level. Nevertheless, the structure set up to administer religious educational institutions was perpetuated: each network has its own national, provincial and local hierarchy, modeled more or less on the equivalent structure of the State, with differences ad pending on the specific organization of each Church. For example, Protestant charter schools are run at the national level by a National Coordination Office which has a general leadership role and manages relations with the state. Provincial offices run all Protestant schools in the province.

Below the provincial level, a coordination office runs the schools under his denomination. The Protestant Church has 66 coordination offices in the country. When a congregation has 40 schools in a province, it has the right to establish a coordinating office there and, if it has 15, to appoint a resident councilor represented at the 
provincial level. Offices are responsible for personnel management (recruitment, transfers, promotions), financial management, as well as pedagogical issues (MURHEGA, 2016).

Therefore, there may be no less than six to ten levels of education administration in the same territorial unit, all of which, in principle, are under the general authority of the MEPSP. Coordinators, at the provincial and lower levels, are proposed by the churches, appointed by the ministry, and financed by contributions paid by students, a proportion of which is levied for the benefit of administrative offices according to standards established by a ministerial circular. At the highest level, the national coordinators of each religious group deal with the ministry.

Parents are the fourth major player in the administration of the school system. They are represented, from the bottom up, by parents' committees in schools, communal and provincial committees and several national parents' organizations, the oldest and most important of which is ANAPECO. Although the main role of national organizations is to encourage parents to send their children into school and to cooperate in the management of schools, parents' committees in schools are now the most important organizations, as they decide, in consultation with management boards, on the amount of "motivation costs", parents' contribution to teachers' remuneration and which constitutes the main part of it; in addition, they are increasingly financing the construction of school buildings. Part of the contributions paid by parents is reserved for the national organization; but, with the decline in their incomes, and consequently in school revenues, the contributions paid to the administrative hierarchy of parents' associations have become irregular (World Bank, 2005).

\subsection{At the base of the system}

All administrative strata converge at the school level. Schools are managed by a head of school (the principal in the case of primary schools, the prefect of studies in the case of secondary schools) and a management board. The head of the school is responsible for the pedagogical, administrative and financial management of the school, including the management of staff, the payment of salaries and all revenues and expenses. The governor, assisted by the Proved, appoints school heads in all public schools; in schools under agreement, the governor exercises his authority in coordination with the provincial coordinators. The management board is the deliberative body of the school. The members of the management board are: the head of school, the director of studies, the pedagogical advisor, the director of discipline, the representative of the teachers and the representative of the parents. The management board has the power to decide on the use of revenues from "operating costs" (parents' contribution to the regular operation of the school) and "motivation costs".

It is clear that there is duplication, lack of clarity and overlap in the functions and responsibilities of many organizational units, even at the central level. For example, the Teachers' Control and Payroll Service (SECOPE), an administrative entity under the direct control of the Secretary-General of the Ministry of EPSP, was created in 1985 to clean up the teachers' pay system. Originally supported by Belgium, this service has developed throughout the country (creation of regional offices, the SECOPE, now SECOPE), has seen its remit expand, and its effectiveness, although currently undermined by financial difficulties, is still widely recognized. SECOPE thus occupies an important place in the administration of the system: management of staff, teacher and non-teacher, of schools and decentralized administrative offices (control of standards, establishment of payment listings), power to proposal the closure of classes or schools, power to proposal sanctions against schools. Thus, these missions led him to build up a considerable database on staff (individual data on civil status, career, qualifications, salaries), but also on schools (class and student sizes). However, all these responsibilities overlap with those of the other central services of the MEPSP; for example, the database provides statistics that are not published, but are duplicated and not entirely consistent with those of the Planning Directorate (MOKONZI G., 2009).

\subsection{Duties and responsibilities}

In such a complex administrative setting, and the division of responsibilities on the ground is determined in practice by access to and control over resources. The two largest contributors are parents (who finance most of the education expenditure: teachers' salaries and construction of new schools) and the central government, which despite its limited financial resources, has the capacity to lead the deployment of teachers and organize exams. The contributions of the EAD and, to a lesser extent, the churches are modest.

For example, the governor should play a major role in the administration of education and in principle EADs should benefit from budget transfers from the Ministry of the Interior, Security and Decentralization, which approves provincial budgets; the governor has authority to execute the budget of the province, and to allocate the amounts required for the operation of the provincial offices of the ministry. In practice, central ministerial expenditures, including payments of salaries of teachers and staff in provincial and lower offices, are financed to a greater extent than non-salaried expenditures of EADs, resulting in control over many schools, classes and teachers as well as on exams, is actually exercised by the central administration.

Among the churches, only a few Catholic congregations have received foreign funding in the last decade; most Protestant churches have not received external funding due to economic sanctions, while the Kimbanguism Church is funded entirely from domestic funds. It follows that the majority of church-run institutions (contract 
schools) are in exactly the same situation as purely public schools (non-contracted schools): teachers' salaries financed mainly by parents' contributions, modest state contributions, parent-funded school construction and a scarcity of investment in improving the quality of education.

\subsection{Teachers and religious coordination's}

They exert strong control over the use of locally generated resources, while parents' participation in the operation of schools remains marginal, despite the importance of their financial contribution. The motivation bonus is distributed to teachers by themselves or by the head of the school; however, the other funds collected are managed by the management board in consultation with religious coordination's (in the case of contracted schools) or administrative agents (in the case of non-contracted schools). Parents have little to say about the use of these funds.

\subsection{Legally}

With regard to the ownership of religious schools receiving public aid. Schools under agreement include schools that have been built by the churches on their own land with their own funds and those that have been built by the state and whose management has been entrusted to the churches. Due to the nationalization and handover of the seventies, it is not clear who owns the land and buildings of the schools under agreement with the Churches or the State and, therefore, who should undertake the new investments in these infrastructures. In practice, communities have contributed to the construction of schools and this lack of legal clarity has not been a major problem so far, but it would need to be addressed if new sources of funding were to emerge.

Despite its complexity, the education administration system works in the DRC. The obvious complexity is partly due to the practical adaptation of the system to changing financing needs and methods, which has created discrepancies between the formal, legal and actual practical frameworks.

Evidence of efficient operation: several hundred thousand teachers continue to receive salaries from the government (although with delays and partially); the deployment of teachers is under control; the various tuition fees are collected in the schools; examinations, both in primary and secondary schools, have been completed every year, including in the eastern provinces and, remarkably, reflects a strong national consciousness, even in Congolese refugee camps abroad.

\section{CONCLUSION AND RECOMMENDATIONS}

In this study I have reviewed the generality on the education system in the Democratic Republic of Congo, in particular on the evolution of the Congolese education system during the periods, the review on the organization of education in the DRC, the financial organization of the education system, the administrative and school organization of the EPSP, the quality and challenges of education in the DRC, the comparison between private and public sector education.

The main mission of basic education in the DRC is to train the Congolese elite who will be the futures of our country but we have seen that the context in which education in the DRC must develop represents a challenge due to years of economic and political chaos, the large size of the country, its low population density, as well as its cultural and ethnic diversity. The wide range of local languages poses unique problems in primary education. Education policy must also respond to the specific needs of a significant number of individuals living in the forest regions of the country, according to different traditions and different means of livelihood, as well as local children; similarly, the new forest sector policy must take these needs into account.

Special programs are also needed for vulnerable groups of children created by war and conflict as child soldiers, street children, refugees and orphans.

The revitalization of the education sector will largely depend on improvements in policy and the economic context, progress in the implementation of public finance reforms, as well as improvements in other sectors. A favorable economic climate, political stability and commitment are necessary prerequisites for the implementation of a policy favorable to the development of the sector. Moreover, the program for political and administrative decentralization, if effectively supported by fiscal decentralization, would require major changes in the system of education administration and in the rules of public funding of primary and secondary education.

In addition to this overall progress, progress in two sectors can immediately improve the demand for and supply of education services: the health sector (in particular by improving the health status of young children) and the roads sector (by making schools more accessible to teachers and students).

Creating a stable and coherent political environment, including a reform of the education administration, is a necessary prerequisite for the development of the education sector. Various political changes in the early eighties were not followed by the establishment of a clear legislative framework, which created confusion and risky growth. A revision of the legal framework applicable to the non-governmental sector consisting of both chartered and nonsubsidized private schools at all levels of education that would clarify mutual rights and obligations, as well as methods of public regulation, is needed to dispel the current confusion and pave the way for a more effective public-private partnership in education. A reform of the administrative structure of the school system and higher 
education is necessary to reduce duplication and to move towards greater decentralization and autonomy of the educational institution.

Providing access to public subsidies to unsubsidized private schools, many of which cater to poor children in urban and semi-urban areas, could be an important way to mobilize additional resources while helping the poor. This requires the creation of a structure responsible for granting these subsidies to private schools and controlling their use. Private schools could, for example, become eligible for subsidies to improve their teaching conditions in return for verifiable results (such as increasing enrolment or improving performance in national examinations). This will require the development of a capacity to administer these subsidies.

Greater devolution of functions to and below the provincial level is desirable in the short term, pending the broader decentralization program, which is expected to take some time to implement. This is especially important to allow the opening of new schools and teaching centers, to make curricula, school calendars and the organization of examinations at primary level more flexible; however, central control over the opening of new schools and the allocation of staff must be maintained to contain expenditure. Material and financial input to strengthen management and administration at decentralized levels will be required.

The existence of management bodies in schools is an achievement that will need to be strengthened in the context of the reform of the education administration. The main weakness of these organs is that parents still do not have a voice in them.

\section{Acknowledgment}

This work would not have been possible without the constant support, guidance, and assistance of my university supervisor professor Chen Tianjun. His level of patience, knowledge, and ingenuity is something I will always keep aspiring to. I would also like to thank my mother Kasongo Malesa for her prayers and encouragements. I would be ungrateful if I did not mention my aunty Veronique Bukumba and my beloved husband Andy Dumevi who were always ready to help with any questions that I had.

\section{REFERENCES}

1. Annuaire statistique de l'enseignement primaire et secondaire et professionnel 2013-2014, cellule technique pour les statistiques de l'éducation. Ministère de l'EPSP. Mars 2014; Statistical Yearbook of Primary and Secondary and Vocational Education 2013-2014, technical unit for education statistics. Ministry of EPSP. March 2014.

2. Banque Mondiale: Le système éducatif de la république démocratique du Congo: Priorités et alternatives, 2005; World Bank: The Education System of the Democratic Republic of congo: Priorities and Alternatives, 2005.

3. Geoffroy Groleau, Improved management and accountability conditions for better access and quality of primary education in the Democratic Republic of Congo?

4. G, MOKONZI, Fourniture efficace des services dans le domaine d'enseignement publique: une étude d'AfriMap, South Africa, open society initiative for South Africa, 2009, P148 ; G, MOKONZI, Efficient Delivery of Services in Public Education: A Study by AfriMap, South Africa, Open Society Initiative for South Africa, 2009, P148

5. Gratien Mokonzi Bambanota, Gratuité et qualité de l'enseignement primaire en Republique Democratique du Congo ; Gratien Mokonzi Bambanota, Free and quality primary education in the Democratic Republic of Congo.

6. https://etreparents.com/la-theorie-de-lorganisation-scolaire-et-ses- caractéristiques

7. http://www.telegramme.fr/decriptage/effectifs scolaires- deux- fois -plus-élevés-bretons-dans-les-privés-1009-2015-107691.php. site visité le 17 juin 2017.

8. Ministère de l'EPSP, Loi-cadre $n^{\circ}$ 14/004, enseignement national, Kinshasa, 11 Février 2014 ; Ministry of EPSP, Framework Law No. 14/004, National Education, Kinshasa, 11 February 2014.

9. MURHEGA M, notes de cours d'éducation comparée, première année de licence, Inédit, ISP/BUKAVU, 2015; MURHEGA M, comparative education course notes, first year of bachelor's degree, Unpublished, ISP/BUKAVU, 2015.

10. MURHEGA, M, cours d'éducation comparée, Inédit ; ISP/BUKAVU, 2016, p.27; 1. MURHEGA, M, comparative education course, Unpublished ; ISP/BUKAVU, 2016, p.27.

11. MURHEGA, M, cours d'histoire de la pédagogie, deuxième année de licence : Inédit ISP/BUKAVU, 2017 , p30; 6. MURHEGA, M, course in the history of pedagogy, second year of bachelor's degree : Unpublished ISP/BUKAVU, 2017, p30

12. MURHEGA M, notes de cours d'éducation comparée, première année de licence, Inédit, ISP/BUKAVU, 2015, p.52; MURHEGA M, notes de cours d'éducation comparée, première année de licence, Inédit, ISP/BUKAVU, 2015, p.52.

13. Rapport de la conférence de Lagos, 1976, pp 13-64 ; Report of the Lagos Conférence, 1976, pp 13-64 
14. Tom De Herdt et Emmanuel Kasongo Munongo, la gratuité de l'enseignement primaire en RDC : attentes et revers de la médaille ; Tom De Herdt and Emmanuel Kasongo Munongo, free primary education in the DRC: expectations and the other side of the coin.

15. . www.wikipedia.org 